\title{
CAPITAL EFFICIENCY AND DEFAULT RISK, EMPIRICAL EVIDENCE FROM COMMERCIAL BANKS IN KENYA
}

\author{
Oduor Joseph Atieno ${ }^{1 i}$, \\ Tobias Olweny², \\ Julius Miroga ${ }^{3}$ \\ ${ }^{1} \mathrm{PhD}$ student, \\ Jomo Kenyatta University \\ of Agriculture and Technology, \\ Kenya \\ ${ }^{2} \mathrm{PhD}$, Lecturer, \\ Jomo Kenyatta University \\ of Agriculture and Technology, \\ Kenya \\ ${ }^{9} \mathrm{PhD}$, Lecturer, \\ Jomo Kenyatta University \\ of Agriculture and Technology, \\ Kenya
}

\begin{abstract}
:
The main objective of this study was to determine effect of capital efficiency on default risk in commercial banks in Kenya. According to the bank supervisory report, the interest rate spread widened to 13 per cent at the end of December 2011 from 10.3 per cent by December 2010 which the CBK Governor termed as a sign of inefficiency in the banking sector. Secondary data was used in the study and descriptive survey design was applied. The target population was 42 Commercial Banks in Kenya out of which 2 were under receivership and 1 was under statutory management. Panel data for 39 commercial banks for the six years period from 2014 to 2019 were obtained from the CBK and individual bank websites. The study was guided by Agency theory, Moral hazard theory and Stakeholders theory. Descriptive statistics, correlation analysis and random and fixed effects were used for secondary data using E-views software. The findings indicated correlation coefficients of capital adequacy and return on equity of -0.14 and -0.11 respectively signifying a negative correlation between capital efficiency and nonperforming loans. It was recommended that capital efficiency be strengthened to reduce non perfuming loans.
\end{abstract}

JEL: G10; G20; G21

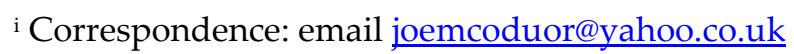


Keywords: capital efficiency, default risk, commercial banks

\section{Introduction}

Capital efficiency refers to the ability of a bank to generate the highest return on capital invested. It relates to the ratio of output in comparison to the amount of capital expenditure involved in maintaining the operation of a bank business (Hyz, 2010). Over the last two decades prior to the credit crisis that started in late 2007, European banking markets became increasingly integrated. The twin forces of deregulation and technological changes contributed to the progressive process of financial integration and increased competition in the financial services industry (European Commercial Banks, 2010).

As a result of this process, there has been a tremendous emphasis on the importance of improved efficiency in the banking sector. That is, it has forced banks to operate closer to the "best practice" or efficient production function. At the same time, this increase in competition could at least in the short-term lead to greater and possibly excessive risk-taking. This is because increased competition reduces the market power of banks thereby decreasing their charter value. The decline in banks' charter values coupled with the banks' limited liability and the existence of 'quasi' flat rate deposit insurance, could encourage banks to take on more risk (Matutes C. \& Vives X., 2018).

In Colombia, since 2002, several regulatory measures have been implemented by the regulators in order to enhance loan loss provisions, and to set adequate capital and liquidity requirements to limit risk-taking. These measures were initially motivated by a profound financial crisis at the end of 1990s that evidenced the vulnerability of the Colombian banking sector to external shocks. Previous studies, although failing to control by risk, have found gains in efficiency of Colombian banks in recent years and have identified that large and foreign banks are more efficient than their counterparts. In this context, recognizing differences in the way risk exposures affect different types of banks becomes relevant in order to get more accurate efficiency estimations and a complete understanding of the effects of risk and macro prudential regulation on bank performance (Sarmiento \& Galán, 2015).

Early studies of banking efficiency have found evidence of low-cost efficiency in the Colombian banking sector during the 90's although some improvements during the first half of 2000 emerged. Recent studies have provided evidence on improvements in technical efficiency and productivity in the sector but large heterogeneity among banks. Using a non-parametric frontier model, a study found that Colombian banks improved in technical efficiency from 2000 up to the global financial crisis of 2007-08, when efficiency and productivity decreased (Sarmiento \& Galán, 2015).

Japanese banking sector had faced considerable problems disposing their bad loans since the early 1990s. The problems became particularly serious in the late 1990s, when several major financial institutions turned out to be in default. To the extent that bank health does matter, deterioration of bank health would tighten the bank's lending 
attitude, and increase the borrowers' default risk, particularly among smaller firms (Fukuyama, 2015)

High levels of default are still being experienced in the Kenyan banking sector. During the year 2013, bad loans jumped by 30.9\% to hit Kshs 80.6 billion, the highest in over six years, even outpacing growth in new credit advanced by the lenders hence crippling the development of the economy (Ngigi, 2014). In Kenya, the ratio of gross nonperforming loans to gross loans increased from 6.8 percent in December 2015 to 9.2 percent in December 2016, subsequently increasing the default risk (Oyuke, 2012). According to the bank supervisory report, the interest rate spread widened to 13 per cent at the end of December 2011 from 10.3 per cent by December 2010 which the CBK Governor termed as a sign of inefficiency in the banking sector (CBK, 2011). Many researchers have analyzed default risk based on variables such as credit policy, interest rates...., while bank efficiency has been overlooked. It is on this basis that the study seeks to establish the effect of bank efficiency on default risk in Commercial Banks in Kenya.

\section{Literature Review}

The study was be guided by Agency theory, Moral hazard theory and Stakeholder theory. The agency theory explains how best to organize relationships in which one party determines the work while another party does the work. In this relationship, the principal hires an agent to do the work, or to perform a task on behalf of the principal. The agency theory proposes that a firm's main objective is to maximize the shareholders wealth (Jensen \& Meckling, 1976).

Moral hazard theory states that widespread medical insurance increases demand for medical care. In other words, there is an increase in risk taking when shielded from consequences (Arrow, 1963).

The stakeholder theory is a theory of organizational management and business ethics that addresses morals and values in managing an organization. Freeman's Strategic Management: A Stakeholder Approach is widely cited in the field as being the foundation of stakeholder theory, although Freeman himself credits several bodies of literature in the development of his approach, including strategic management, corporate planning, systems theory, organization theory, and corporate social responsibility.

\section{Conceptual Framework}

Independent Variable

\section{Capital Efficiency}

- Net operating income to equity ratio

- Capital adequacy ratio

- Net operating income to capital
Dependent Variable

\section{Default Risk}

- Non-performing loans to total asset ratio 
Altunbas et al., 2017 examined in their study the relationship between capital, risk and efficiency in European banking for the period 2005-2013. According to the results of empirical evidence banks with more capital tend to be less efficient and also the ones to take on excessive risk while they didn't find any incentive to take on more risk in case of inefficient European banks. The results show a positive relationship between risk and capital level and the positive influence that financial strength of the corporate sector has in reducing capital levels and bank risk-taking. In the case of commercial and saving banks there are no major differences in this relationship while co-operative banks capital levels are inversely related to risks.

Cihak M. \& Podpiera R. J., (2015), in a study on three East African countries, using 43 banks from Kenya, 23 banks from Tanzania and 17 banks from Uganda, financial service reforms find the banks in Kenya, Tanzania and Uganda to be inefficient. Using 137 commercial banks from 29 African countries, (Kablan, 2014) investigates the level and determinants of bank cost efficiency from 2008 to 2012. The author finds the banks to be cost efficient using stochastic frontier analysis. Applying dynamic system generalized method of moments, the author reports a negative relationship between nonperforming loans and efficiency. In addition, bank capitalization is statistically significant and negatively related to bank efficiency.

Casu et al., 2015 used a sample of 530 banks from five European Union countries: France, Germany, Italy, Spain and the United Kingdom covering the period 2008 to 2012 to investigate existence and convergence of productive efficiency across the European banking markets since the introduction of the Single Internal Market. Their results show evidence of a small improvement in bank efficiency levels since the European Union's Single Market Programme, but a weak evidence of convergence. They also assess the determinants of European bank efficiency using the bootstrapping technique to DEA efficiency scores and Tobit regression model approach. Their results suggest that there is little evidence that the average capital has effect on bank efficiency levels.

Contrary to the growing bank literature on static efficiency, Berger A. N. \& DeYoung R. (2017) uses Granger-causality method, a dynamic approach to examine the intertemporal relationships between problem loans, cost efficiency and capital for a sample of U.S. commercial banks between 1985 and 1994. The authors find that improvement in non-performing loans tends to be followed by the reduction in cost efficiency and decreases in cost efficiency precede increases in non-performing loans indicating that the intertemporal relationships between loan quality and cost efficiency run in both directions.

Using banks from 17 transition European economies from 2009 to 2012, Grigorian D. A. \& Manole V. (2016) found the banks in these countries to be inefficient. On the factors influencing the bank efficiency, the authors find that capitalization is positive and has significant effect on bank efficiency. Their findings also show that inflation has insignificant effect on bank efficiency.

Rangan N. Grabowski R. Aly H. Y. \& Pasurka C., (2018) in a study of consolidated banking institutions instead of bank branches employing a sample of 215 US banks in 
2014. They also use the DEA method and adopt the intermediation approach using labour, capital and purchased funds as input and loans and deposits as output variables. Their study reveals the banks are inefficient and that scale inefficiencies of the banks are relatively small, identifying technical inefficiency as the key source of inefficiency.

Yeh (2016) applies both DEA and financial ratio analysis to examine the efficiency of six commercial banks in Taiwan over the period 2003 to 2012. Yeh (2016) uses interest expenses, non-interest expenses, and total deposits as input variables and interest income, non-interest income, and total loans as output variables. The author's result shows that the banks with high DEA scores have higher ratios in capital adequacy, asset utilization and profitability and lower ratios in financial leverage and liquidity. The author then infers that it is possible to link the estimated efficiencies with banks' actual financial operating decisions.

Fukuyama (2015) applies the DEA approach to examine bank efficiency in 143 Japanese commercial banks in 2010 using labour, capital and funds from customers as input variables and income from loans and other business activities as output variables. The author finds the mean level of pure technical efficiency to be 0.8645 and scale efficiency around 0.9844 indicating that the major source of overall technical inefficiency is pure technical inefficiency. The author attributes the scale inefficiency mainly to increasing returns to scale. Scale efficiency has positive but weak effect on bank size.

Resti (2017) employs the DEA method to evaluate a panel of 270 Italian banks for the period 2010-2014. The author adopts the intermediation approach and use labour and capital as input variables and loans, deposits, and non-interest income as output variables. Resti (2017) observes no increase in efficiency but large differences in the efficiency scores. The result also reveals positive association between efficiency and assets quality. Pasiouras (2018) employs the DEA approach to assess the efficiency of the Greek commercial banking industry over the period 2010-2014 including Greek banks operating abroad. The study results show that banks operating abroad are more technical efficient than those operating at the national level. In order to investigate the determinants of efficiency, the author applies the Tobit analysis with technical and scale efficiency as dependent variables.

\section{Material and Methods}

\subsection{Research Design}

The study adopted descriptive survey research design to meet its research objectives. This was appropriate in this study since surveys are useful in describing the characteristics of a large population. No other research method can provide this broad capability, which ensures a more accurate sample to gather targeted results from which to draw conclusions and make important decisions. 


\subsection{Target Population}

The target population was all the 42 Commercial Banks in Kenya as at 2019 by Central Bank of Kenya (CBK, 2020).

\subsection{Data Collection Instruments}

Secondary data was collected using audited and published financial statements from the websites of the Central Bank of Kenya to establish the relationship between bank efficiency and default risk in commercial banks in Kenya.

\subsection{Data Collection Procedure}

Panel data technique for a period of six years from 2014 to 2019 was employed to determine the effect of bank efficiency on default risk in commercial banks in Kenya. Secondary data was collected from the Central Bank of Kenya website as well as from the websites of the individual commercial banks. Audited and published Financial Statements for the period 2012 to 2017 were obtained from the Central Bank of Kenya websites and also from the websites of the individual commercial banks.

\subsection{Data Analysis and Presentation}

Data was analyzed using E-views software. Model specification estimation and rationale of variables was done. Secondary data was tested for normality and transformed into natural logarithm before regression was undertaken. Regression co-efficient between the independent and the dependent variable was therefore established. Data was presented using tables.

\subsection{Model Specification and Rationale of Variables}

In order to check which variables were highly correlated so as to avoid the problem of multi-collinearity which is a common problem in time series data, correlation analysis was used. The data included time series and cross-sectional data that were pooled into a panel data set and then estimated using panel data regression. Data was converted to their natural logs and multiple regression conducted in order to deal with the problem of large numbers and eliminate Heteroscedasticity. This thesis employed multiple panel unit root tests that can be arranged in groups by cross section dependence or independence homogenous, or heterogeneous unit roots that are defined by Im Pesaran \& Shin (2003) \& Levin et al., (2002). Individual unit root has limited powers hence the probability of rejecting null hypothesis when it's false. Common unit root process Levin, Lin and Chu panel unit root test was used and for individual unit root process the thesis used three types of panel unit root tests, Im, Pesaran and Shin panel unit root test, ADFFisher chi-square test and the Phillips-Perron -Fisher Chi square panel unit root test. 


\section{Results and Discussion}

Net operating income to capital had a coefficient of 0.42 and a significant probability value of 0.0187 which is significant at 5 percent level of significance which means that when net operating income to capital increases by 0.42 percent per year then nonperforming loans increase by 1 percent in the same year. Capital Adequacy had a coefficient of -0.46 and an insignificant probability value of 0.16 . This means that capital adequacy had no significant effect on non-performing loans during the study period. They have a negative relationship which is not significant. Net operating income to capital had a coefficient of 0.42 and a significant probability value of 0.0187 which is significant at 5 percent level of significance which means that when net operating income to capital increases by 0.42 percent per year then non-performing loans increase by 1 percent in the same year.

\section{Recommendations}

The study recommends a calculated effort to improve capital efficiency in order to reduce loan defaults.

\section{Conclusion}

Capital efficiency has a significant effect on reducing non-performing loans. When net operating income to capital increases by 0.42 percent per year then non-performing loans decrease by 1 percent in the same year. This therefore indicates if capital efficiency is improved, loan defaults will greatly reduce.

\section{Conflict of Interest Statement}

The authors declare no conflicts of interests.

\section{About the Author}

The author is a university lecturer, a PhD student at Jomo Kenyatta University of Agriculture and Technology, Kenya and is currently involved in writing research papers in Finance and Accounting. The researcher has equally presented research papers in a number of conferences both in local and international fora.

\section{References}

Altunbas Y., Carbo S., Gardener E. P. M. \& Molyneux P. (2017). Examining the relationships between capital, risk and efficiency in European banking. European Financial Management, 49-70.

Arrow, K. J. (1963). American Economic Review, 941-973. 
Bauer P. W., Berger A. N., Ferrier G. D. \& Humphrey D. B. (2018). Consistency Conditions for Regulatory Analysis of financial Institutions: A comparison of Frontier Efficiency methods. Journal of Economics and Business, Vol. 50 (2), 85-114.

Casu B., Girardone C. \& Molyneux P. (2015). Productivity change in European banking: A comparison of parametric and non-parametric approaches. Journal of Banking and Finance, 28(10), 2521-2540.

C. B. K. (2011). Bank Supervision report. Nairobi, Kenya: CBK Publishers.

Cihak M. \& Podpiera R. J. (2015). Bank behaviour in developing countries: Evidence from east Africa" IMF Working Paper.

Eisenhardt, M. (1989). Agency Theory. An Assessment and Review 14(1), 57-74.

Fukuyama, H. (2015). Technical and scale efficiency of Japanese commercial banks: A Non-parametric approach. Applied Economics, 25, 1101-1112.

Grigorian D. A. \& Manole V. (2016). Determinants of Commercial Bank Performance in Transition: An Application of Data Envelopment Analysis. World Bank Policy Research Working Paper, 2850.

Hyz, A. (2010). Job satisfaction and employee performance of Greek banking staff: An empirical Investigation. Acta universitatis lodziensis Folia oeconomica, 239.

Im Pesaran K. \& Shin Y. (2003). Testing for unit roots in heterogeneous panels. Journal of Econometrics, 115, 53-74.

Kablan, S. (2014). Banking efficiency and financial development in Sub-Saharan Africa. IMF Working Paper WP/10/136.

Levin A., Lin C. \& Chu C. (2002). Unit root tests in panel data: Asymptotic and nitesample properties. Journal of Econometrics 108, 1-24.

Matutes C. \& Vives X. (2018). Imperfect competition, risk taking, and regulation in banking. European Economic Review 44, 1-34.

Ngigi, G. (2014). High interest rates leave banks with Sh70bn in bad loans: Banks feel the heat of new CBK order on bad loans. Nairobi: Business Daily.

Oyuke, J. (2012). Treasury in new bid to tame rogue banks. The Standard Newspaper.

Rangan N. Grabowski R. Aly H. Y. \& Pasurka C. (2018). The technical efficiency of US banks. Economics Letters, 28, 169-175.

Yeh, Q. (2016). The application of data envelopment analysis in conjunction with financial ratios for bank performance evaluation. Journal of the Operational Research Society, $47,980-988$. 


\section{Appendix}

\section{a. Natural log of Net Operating Income to Capital}

Im, Pesaran and Shin unit root test, Augmented Dickie-Fuller ADF-Fisher Chi-square, Phillips-Perron Fisher Chi square, the Levin, Lin \& Chu $t^{*}$ statistic for LN_NOI show probability of less than 0.005 . Therefore, we reject the null hypothesis that LN_NOIC has a unit root.

Panel unit root test: Summary

Series: LN_NOIC

Sample: 20142019

Exogenous variables: Individual effects

Automatic selection of maximum lags

Automatic lag length selection based on SIC: 0

Newey-West automatic bandwidth selection and Bartlett kernel

Table 1: Unit Root Test for LN_NOIC

\begin{tabular}{llllc} 
Method & Statistic & Prob. ${ }^{* *}$ & $\begin{array}{c}\text { Cross- } \\
\text { sections }\end{array}$ & Obs \\
\hline Null: Unit root (assumes common unit root process) & & & & 177 \\
\hline Levin, Lin \& Chu t* & -9.58595 & 0.0000 & 36 & \\
& & & & 177 \\
Null: Unit root (assumes individual unit root process) & & & & 177 \\
Im, Pesaran and Shin W-stat & -0.81108 & 0.2087 & 36 & 177 \\
ADF - Fisher Chi-square & 84.6221 & 0.1467 & 36 & \\
PP - Fisher Chi-square & 113.902 & 0.0012 & 36 & \\
& & & &
\end{tabular}

** Probabilities for Fisher tests are computed using an asymptotic Chi-square distribution. All other tests assume asymptotic normality.

\section{b. Natural log of Net Operating Income to Equity}

All the stationery tests rejected the null hypothesis of NOIE because the Levin, Lin \& Chu $\mathrm{t}^{*}, \mathrm{Im}$, Pesaran and Shin unit root test, Augmented Dickie-Fuller ADF-Fisher Chi-square, Phillips-Perron Fisher Chi square had a probability value of less than 0.05 . Therefore, we reject the null hypothesis that LN_NOIE has a unit root.

Panel unit root test: Summary

Series: LN_NOIE

Sample: 20142019

Exogenous variables: Individual effects

Automatic selection of maximum lags

Automatic lag length selection based on SIC: 0

Newey-West automatic bandwidth selection and Bartlett kernel 
Table 4.2: Unit Root Test for NL_NOIE

\begin{tabular}{lcccc} 
Method & Statistic & Prob. $^{* *}$ & $\begin{array}{c}\text { Cross- } \\
\text { sections }\end{array}$ & Obs \\
\hline Null: Unit root (assumes common unit root process) & & & & \\
\hline Levin, Lin \& Chu t* & -8.88913 & 0.0000 & 36 & 177 \\
& & & & \\
Null: Unit root (assumes individual unit root process) & -1.16674 & 0.1217 & 36 & 177 \\
Im, Pesaran and Shin W-stat & 99.1354 & 0.0187 & 36 & 177 \\
ADF - Fisher Chi-square & 125.738 & 0.0001 & 36 & 177 \\
PP - Fisher Chi-square & & & & \\
& & &
\end{tabular}

** Probabilities for Fisher tests are computed using an asymptotic Chi-square distribution. All other tests assume asymptotic normality.

\section{c. Natural log of Operating Cost to Asset}

The Levin, Lin \& Chu t $^{*}$ statistic, Im, Pesaran and Shin unit root test, Augmented DickieFuller ADF-Fisher Chi-square, Phillips-Perron Fisher Chi square for LN_OC FOR ALL variables were all less than 0.005 . Therefore, we reject the null hypothesis that LN_OC has a unit root. This is shown in table 4.10 below.

Panel unit root test: Summary

Series: LN_OC

Sample: 20142019

Exogenous variables: Individual effects

Automatic selection of maximum lags

Automatic lag length selection based on SIC: 0

Newey-West automatic bandwidth selection and Bartlett kernel

Table 4.10: Unit Root Test for LN_OC

\begin{tabular}{lllll}
\hline \hline & & & \\
Method & Statistic & Prob. $^{* *}$ & $\begin{array}{c}\text { Cross- } \\
\text { sections }\end{array}$ & Obs \\
\hline Null: Unit root (assumes common unit root process) & & & & 172 \\
\hline Levin, Lin \& Chu t* & -8.45703 & 0.0000 & 35 & \\
Null: Unit root (assumes individual unit root process) & & & & 172 \\
\hline Im, Pesaran and Shin W-stat & -0.95540 & 0.1697 & 35 & 172 \\
ADF - Fisher Chi-square & 82.8496 & 0.1398 & 35 & 172 \\
PP - Fisher Chi-square & 115.214 & 0.0005 & 35 & \\
& & & &
\end{tabular}

** Probabilities for Fisher tests are computed using an asymptotic Chi-square distribution. All other tests assume asymptotic normality. 
Creative Commons licensing terms

Authors will retain copyright to their published articles agreeing that a Creative Commons Attribution 4.0 International License (CC BY 4.0) terms will be applied to their work. Under the terms of this license, no permission is required from the author(s) or publisher for members of the community to copy, distribute, transmit or adapt the article content, providing a proper, prominent and unambiguous attribution to the authors in a manner that makes clear that the materials are being reused under permission of a Creative Commons License. Views, opinions and conclusions expressed in this research article are views, opinions and conclusions of the author(s). Open Access Publishing Group and European Journal of Economic and Financial Research shall not be responsible or answerable for any loss, damage or liability caused in relation to/arising out of conflict of interests, copyright violations and inappropriate or inaccurate use of any kind content related or integrated on the research work. All the published works are meeting the Open Access Publishing requirements and can be freely accessed, shared, modified, distributed and used in educational, commercial and non-commercial purposes under a Creative Commons Attribution 4.0 International License (CC BY 4.0). 